\title{
The Impact of Enterohemorrhagic Escherichia coli (EHEC) on Ciliate Protozoan Populations in Municipal Sewage
}

\author{
Zhen Li1,2*, Peter P. Sheridan', Malcolm S. Shields ${ }^{3}$ \\ ${ }^{1}$ Department of Biological Sciences, Idaho State University, Pocatello, Idaho, USA \\ ${ }^{2}$ Washington State Department of Health, Public Health Laboratories, Shoreline, Washington, USA \\ ${ }^{3}$ Siemens Clinical Laboratory, Berkeley, California, USA \\ Email: " lizhen@isu.edu
}

Received 29 July 2015; accepted 24 August 2015; published 27 August 2015

Copyright (C) 2015 by authors and Scientific Research Publishing Inc.

This work is licensed under the Creative Commons Attribution International License (CC BY). http://creativecommons.org/licenses/by/4.0/

c) (i) Open Access

\begin{abstract}
Enterohemorrhagic Escherichia coli strains (EHEC) have caused many foodborne outbreaks. Bacterivorous protozoa could remove bacteria from aquatic systems. We analyzed the ciliate protozoan population changes influenced by EHEC co-culture in activated sludge. EHEC and non-EHEC control $E$. coli cells were added to activated sludge samples in microcosms. The ciliate population changes were monitored by terminal restriction fragment length polymorphism (T-RFLP) analysis. EHEC and non-EHEC fed ciliate protozoan populations were different from each other and the no bacteria added controls based on the additive main effects and multiplicative interaction model (AMMI) analysis. Ciliate species were identified by $18 S$ rDNA clone libraries. The $18 \mathrm{~S}$ rDNA clones from the original sludge sample were identified as Epistylis wenrichi $(70 \%)$ and Prorodon teres $(30 \%)$, while clones from EHEC treated sludge sample were identified as $P$. teres $(52 \%)$, Vorticella fusca (41\%), Dexitrichides pangi (5\%), and Opisthonecta henneguyi (2\%). This study could provide helpful information about ciliate protozoan population changes caused by different $E$. coli strains in wastewater treatment plants, which could be useful for preventing and tracking $E$. coli outbreaks.
\end{abstract}

\section{Keywords}

$18 S$ rDNA, Activated Sludge, Protozoa, Enterohemorrhagic E. coli, T-RFLP

\footnotetext{
"Corresponding author.
}

How to cite this paper: Li, Z., Sheridan, P.P. and Shields, M.S. (2015) The Impact of Enterohemorrhagic Escherichia coli (EHEC) on Ciliate Protozoan Populations in Municipal Sewage. Advances in Microbiology, 5, 668-676. 


\section{Introduction}

Enterohemorrhagic Escherichia coli strains (EHEC) have caused increased cases of worldwide foodborne E. coli outbreaks [1]-[3]. E. coli O157:H7 strain EDL 933 was first isolated in 1982 from an E. coli outbreak which caused hemorrhagic colitis and hemolytic-uremic syndrome (HUS) [4]. The major virulence factor of EHEC is the Shiga toxin, which is produced by E. coli in two forms: Stx1 and Stx2. It was first reported in 1983 that EHEC also made Shiga toxin [5]. The stx genes are encoded on lysogenic lambdoid bacteriophages in the E. coli genome, which can be expressed in the lytic cycle of the bacteriophage [6]. Stx toxins may have evolved as a bacterial defense against protozoan predators, such as the ciliate Tetrahymena thermophila [7] [8]. Steinberg and Levin [7] found that the ratio of Stx ${ }^{+}$to Stx ${ }^{-}$E. coli increased under the predation of T. thermophila. Lainhart et $a l$. [8] further confirmed that $T$. thermophila can be killed by either stx-carrying EHEC strain EDL 933 or purified Stx protein.

Many EHEC outbreaks have been associated with contaminated food products and water [9] [10]. EHEC can be transmitted from contaminated cattle manure and irrigation water to agricultural products, such as lettuce [11] [12]. Ravva et al. [10] showed that E. coli O157:H7 failed to proliferate in dairy lagoon wastewater microcosms, indicating that EHEC could be removed from wastewater system. Some ciliate protozoa were found to be resistant to E. coli O157:H7 and also able to reduce E. coli populations in dairy lagoon wastewater [13].

Pathogens in urban sewage could reflect infections in human populations [14]. E. coli, as well as total and fecal coliform bacteria, has been used as indicators for wastewater treatment efficiency [15]. EHEC and other stx-positive E. coli strains have been found in municipal sewage [16] [17]. Moreover, bacteriophages carrying $s t x_{2}$ genes were also discovered in municipal sewage [18]. Thus, the sewage systems in urban areas could be potential reservoirs for EHEC evolution.

Protozoa are unicellular eukaryotes and bacterivorous protozoan species are considered to be important in shaping the structure of bacterial communities in planktonic as well as terrestrial ecosystems [19]. Activated sludge from wastewater treatment plants is a known reservoir for both bacterial and protozoan populations [20] [21]. Protozoan populations have been used as indicators of wastewater treatment plant performance [20] [22]. Protozoan population numbers could be as high as 50,000 cells per $\mathrm{ml}$ in the activated sludge in wastewater treatment plants [20]. Ciliates are the dominant protozoa in sewage [20] [22] [23]. Ciliate protozoan bacterivory of both pathogenic and non-pathogenic E. coli could remove up to $95 \%$ of $E$. coli in the activated sludge system of domestic sewage treatment plants [20].

The stx genes were detected in Pocatello wastewater treatment plant in Pocatello, Idaho, USA [24]. Municipal wastewater is collected from a population of approximately 60,000 people, and treated with an activated sludge system. The effluent is chlorinated and discharged into Portnuef River in Pocatello and solid waste is recycled on local agricultural fields as fertilizer. In order to understand the ciliate protozoan responses to EHEC in the activated sludge of municipal sewage ecosystems, the protozoan population changes were monitored under the influence of EHEC strain EDL 933 by terminal restriction fragment length polymorphism (T-RFLP) analysis. Ciliate protozoa species resistant to EHEC were also identified by 18S rDNA clone libraries.

\section{Materials and Methods}

\subsection{Sample Collection and Microcosms Set Up}

The activated sludge samples were collected from the wastewater treatment plant in Pocatello, Idaho, USA. To construct a microcosm, 1 liter of sludge samples was added to an Erlenmeyer flask and kept at $20^{\circ} \mathrm{C}$. Fresh air was pumped into each microcosm at $27.5 \mathrm{ml} \cdot$ second $^{-1}$ to simulate the aeration process in the sewage treatment plant.

E. coli strains used in this study were EHEC strain EDL 933 provided by the National Food Safety \& Toxicology Center at Michigan State University, and non-EHEC strain K-12 received from American Type Culture Collection (ATCC). E. coli cells were cultured in Luria-Bertani (LB) medium and collected at log phase. E. coli cells were kept in $0.1 \%$ peptone solution at $4 \times 10^{10} \mathrm{ml}^{-1}$ colony forming unit (CFU) [25]. Ten milliliters of $E$. coli solution was added to each microcosm every 2 days. One set of 3 microcosms included one EHEC added microcosm, one K-12 added microcosm and one control microcosm without any bacteria added. The experiment was repeated in triplicate.

Samples were collected from one set of microcosms at day 0, 2 and 4 for total bacterial counts. The total bac- 
terial counts were performed using the serial dilution method on LB agar plates [26]. Sample collection for T-RFLP analysis was done according to Li et al. [27]. Briefly, $1 \mathrm{ml}$ of sludge sample was collected as the control sample before the sludge was added to each microcosm at day 0 . At day 10 and $25,1 \mathrm{ml}$ of suspended sludge sample was collected from each microcosm. DNA was extracted using the FastDNA ${ }^{\circledR}$ SPIN Kit for Soil Kit (MP Biomedicals, Santa Ana, CA, USA). Each DNA sample was equally divided into 3 aliquots and stored at $-20^{\circ} \mathrm{C}$ before PCR amplification.

At day $0,1 \mathrm{ml}$ of sewage sample was collected from one of the control microcosms for 18S rDNA analysis. At day 53, $1 \mathrm{ml}$ of sewage sample was collected from one of the three EDL 933-added sewage microcosms for 18 SDNA analysis. The FastDNA ${ }^{\circledR}$ SPIN Kit for Soil Kit (MP Biomedicals, Santa Ana, CA, USA) was used to extract total DNA from activated sludge samples.

\subsection{S rDNA Gene Clone Library}

PCR amplification of ciliate specific18S rDNA was carried out with the following primers: 384F (YTB GAT GGT AGT GTA TTG GA) and 1147R (GAC GGT ATC TRA TCG TCT TT) [28]. PCR amplification reactions were carried out in $50 \mu \mathrm{l}$ reactions containing $1 \times$ PCR buffer, dNTPs at $0.8 \mathrm{mM}$ each, $2 \mathrm{mM} \mathrm{MgCl}$, each primer at $0.4 \mu \mathrm{M}, 1.25 \mathrm{U}$ of Takara Ex Taq polymerase (Clonetech, Mountain View, CA, USA), and $0.2 \mu \mathrm{g}$ non-acetylated BSA (Promega, Madison, WI, USA) in a PCT-200 Peltier Thermal Cycler (MJ Research Inc., Watertown, MA, USA). Amplification conditions were $94^{\circ} \mathrm{C}$ for $1 \mathrm{~min}$, held at $80^{\circ} \mathrm{C}$ for addition of dNTPs (hot start), followed by 30 cycles of $94^{\circ} \mathrm{C}$ for 45 seconds, $55^{\circ} \mathrm{C}$ for $1 \mathrm{~min}$, and $72^{\circ} \mathrm{C}$ for $1.5 \mathrm{~min}$, followed by a final extension at $72^{\circ} \mathrm{C}$ for $10 \mathrm{~min}$. Amplified $18 \mathrm{~S}$ rDNA gene fragments were cloned into pGEM ${ }^{\circledR}$-T Easy Vector (Promega, Madison, WI, USA) and transformed into E. coli DH5 $\alpha$ according to the manufacturer's instructions. Recombinant colonies from each source were identified from Ampicillin/X-gal plates. The plasmid DNA was extracted using the alkaline-lysis mini-preparation method [29]. The plasmids were grouped according to restriction fragment length polymorphism patterns following double digestion by RsaI and MspI (Promega, Madison, WI, USA) and visualization by $2 \%$ agarose gel electrophoresis [30]. Plasmid inserts from representative clones of each unique RFLP group were sequenced with the SP6 primer (TACGATTTAGGTGACACTATAG). Basic Local Alignment Search Tool (BLAST) was used to identify ciliate species from the 18S rDNA gene sequences based on the highest identity scores. Selected clones with different BLAST search results were used for sequencing with the T7 primer (TAATACGACTCACTATAGGG). Vector NTI Suite 9 (Invitrogen Corporation, Carlsbad, CA, USA) was used to align contiguous sequences. RDP3 was used to detect possible chimeric sequences from clone libraries [31]. Assembled contig sequences were searched against GenBank accessions via BLAST, and the matched ciliate species with highest identity scores were identified. MEGA 5 was used to construct the phylogenetic tree using the maximum likelihood method [32]. The sequences of $18 \mathrm{~S}$ rDNA clones and the closely related ciliate species sequences obtained from the NCBI database were used in the phylogenetic tree with Paramecium tetraurelia as the outgroup.

\subsection{T-RFLP Analysis}

T-RFLP analysis was conducted according to Liu et al. [33] by using fluorescently labeled 18S rDNA primers: 5'FAM-384F and 5'HEX-1147R. PCR conditions were the same as the 18S rDNA clone library experiments. PCR products were purified and washed with $200 \mu \mathrm{TE}$ in the Montage ${ }^{\circledR}$ PCR spin columns (Millipore, Bedford, MA, USA) and resuspended in $30 \mu \mathrm{l} \mathrm{TE}$. Aliquots of $15 \mu \mathrm{l}$ were digested with MspI and RsaI separately and incubated overnight at $37^{\circ} \mathrm{C}$. The digested mix was amended with $2 \mu \mathrm{l}$ of $2.5 \mathrm{M}$ sodium acetate, $\mathrm{pH}$ 5.2, and precipitated with $60 \mu \mathrm{l}$ isopropanol overnight at $4^{\circ} \mathrm{C}$. The pellet was recovered after $10 \mathrm{~min}$ of centrifugation at $16,100 \times \mathrm{g}$ and washed with $70 \%$ ethanol, vacuum dried and resuspended in $5 \mu \mathrm{l}$ TE. T-RFLP analyses of the fluorescently labeled fragments were performed with an ABI 3100 automated capillary DNA-sequencer (Applied Biosystems Instruments, Foster City, CA, USA) at the ISU Molecular Research Core Facility. T-RFLP analysis expedited (T-REX) software [34] was used to analyze the T-RFLP tabulated data exported from Peak Scanner $^{\mathrm{TM}}$ software (Applied Biosystems Instruments, Foster City, CA), using the additive main effects and multiplicative interaction model (AMMI) [35]. The terminal restriction fragments (T-RFs) were processed with the following parameters: Noise filtering (peak area standard deviation multiplier $=1$ ), T-RF alignment (clustering threshold $=0.5$ ), T-RFs omitted if they occurred in less than $2 \%$ of samples, "sample name" and "day" were chosen as environments. One-way analysis of variance (ANOVA) was used to compare the numbers of 
T-RFs among different samples [36].

\subsection{Nucleotide Sequence Accession Numbers}

Partial 18S rDNA sequences were deposited in Gen Bank under accession numbers JX667685 through JX667704.

\section{Results}

\subsection{Bacterial Counts}

The total bacterial cell count from the original activated sludge was $1.7 \times 10^{4} \mathrm{ml}^{-1}$ from one set of 3 microcosms. The total bacterial cell count from the K-12-added microcosm changed from $3.4 \times 10^{8} \mathrm{ml}^{-1}$ (with K-12 cells added), to $1.2 \times 10^{6} \mathrm{ml}^{-1}$ after 2 days, to $1.5 \times 10^{4} \mathrm{ml}^{-1}$ after 4 days. The total bacterial cell count of EDL 933-added microcosm changed from $5.8 \times 10^{8} \mathrm{ml}^{-1}$ to $1.5 \times 10^{6} \mathrm{ml}^{-1}$ after 2 days, to $1.3 \times 10^{4} \mathrm{ml}^{-1}$ after 4 days. This could indicate that the EDL 933 and K-12 cells were removed at approximately the same rate in microcosms. Based on this result, fresh E. coli solution at $4 \times 10^{10} \mathrm{ml}^{-1} \mathrm{CFU}$ was added to each microcosm to reach $10^{8} \mathrm{ml}^{-1}$ final concentration every 2 days.

\subsection{S rDNA Clone Libraries}

Based on the ciliate18S rDNA sequencing results, several ciliate species were identified (Table 1). Epistylis wenrichi was the most commonly found ciliate in the original sludge sample before the treatment ( $70 \%$ in 79 clones),

Table 1. BLAST search results of ciliate 18S rDNA clones from EDL 933-treated ciliate population after 53 days and no bacteria added control at day 0 .

\begin{tabular}{|c|c|c|c|c|c|}
\hline $\begin{array}{l}\text { Sequenced Clones } \\
\text { (accession number) }\end{array}$ & $\begin{array}{l}\text { Number of } \\
\text { clones }^{\mathrm{a}}\end{array}$ & $\begin{array}{l}\text { GenBank closest match } \\
\text { (accession number) }\end{array}$ & Identity (\%) & Class & Family \\
\hline \multicolumn{6}{|c|}{ EDL 933 added microcosm } \\
\hline 1 (JX667699) & 1 & Prorodon teres (X71140) & 96 & Prostomatea & Prorodontidae \\
\hline $3(\mathrm{JX} 667700)$ & 1 & Prorodon teres (X71140) & 96 & Prostomatea & Prorodontidae \\
\hline 7 (JX667701) & 1 & Prorodon teres (X71140) & 96 & Prostomatea & Prorodontidae \\
\hline 8 (JX667702) & 2 & Prorodon teres (X71140) & 96 & Prostomatea & Prorodontidae \\
\hline 11 (JX667687) & 2 & Prorodon teres (X71140) & 96 & Prostomatea & Prorodontidae \\
\hline 18 (JX667703) & 22 & Prorodon teres (X71140) & 96 & Prostomatea & Prorodontidae \\
\hline 2 (JX667685) & 3 & Dexitrichides pangi (AY212805) & 95 & Oligohymenophorea & Philasteridae \\
\hline $4((J X 667686)$ & 22 & Vorticella fusca (JN120230) & 98 & Oligohymenophorea & Vorticellidae \\
\hline 48 (JX667704) & 1 & Vorticella fusca (JN120230) & 98 & Oligohymenophorea & Vorticellidae \\
\hline 13 (JX667688) & 1 & Opisthonecta henneguyi (JN120201) & 97 & Oligohymenophorea & Opisthonectidae \\
\hline \multicolumn{6}{|c|}{ Control microcosm at day 0} \\
\hline 6A (JX667691) & 5 & Prorodon teres (X71140) & 96 & Prostomatea & Prorodontidae \\
\hline 50A (JX667695) & 10 & Prorodon teres (X71140) & 96 & Prostomatea & Prorodontidae \\
\hline 51B (JX667698) & 6 & Prorodon teres (X71140) & 96 & Prostomatea & Prorodontidae \\
\hline 34B (JX667690) & 3 & Prorodon teres (X71140) & 96 & Prostomatea & Prorodontidae \\
\hline 17A (JX667692) & 21 & Epistylis wenrichi (AF335515) & 93 & Oligohymenophorea & Epistylidae \\
\hline 27A (JX667693) & 19 & Epistylis wenrichi (AF335515) & 97 & Oligohymenophorea & Epistylidae \\
\hline 49A (JX667694) & 5 & Epistylis wenrichi (AF335515) & 95 & Oligohymenophorea & Epistylidae \\
\hline 5B (JX667689) & 3 & Epistylis wenrichi (AF335515) & 97 & Oligohymenophorea & Epistylidae \\
\hline 7B (JX667696) & 4 & Epistylis wenrichi (AF335515) & 96 & Oligohymenophorea & Epistylidae \\
\hline 20B (JX667697) & 3 & Epistylis wenrichi (AF335515) & 97 & Oligohymenophorea & Epistylidae \\
\hline
\end{tabular}

${ }^{\mathrm{a}}$ Total number of clones that shared the same RFLP patterns with the sequenced clones. 


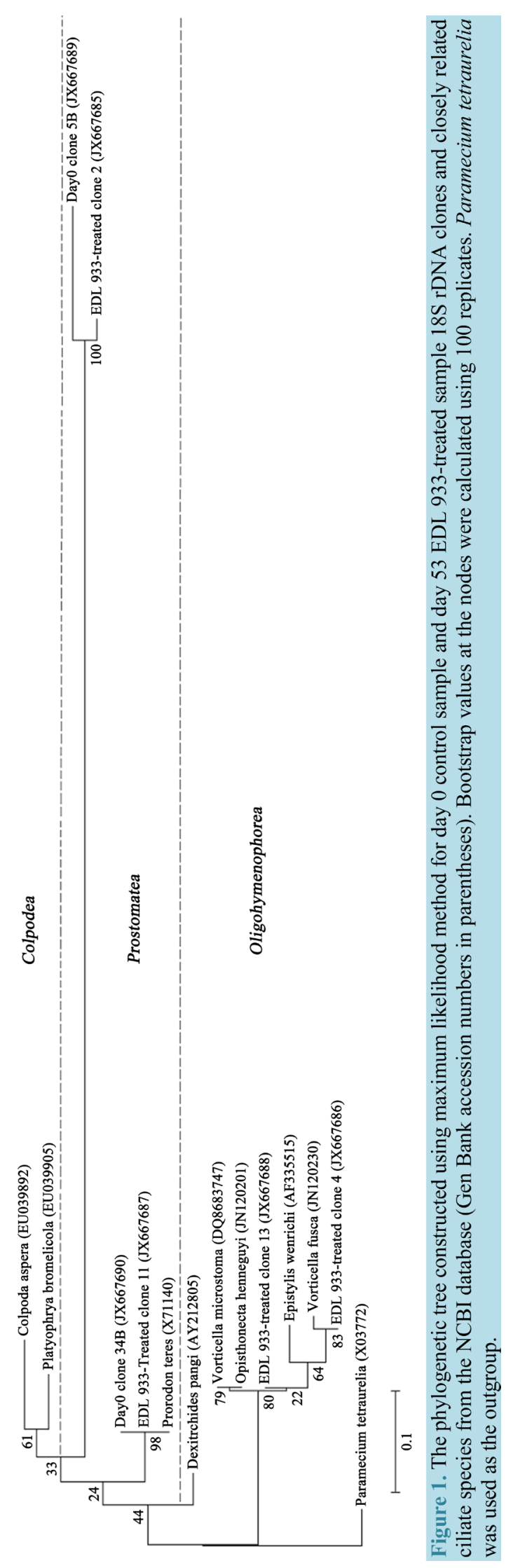


but it was not detected in the EDL 933-treated sludge sample. Prorodon teres was common in both the EDL 933-treated sludge sample (52\% in 56 clones) and the untreated original sludge sample (30\% in 79 clones). From the EDL 933-treated sludge sample, $41 \%$ were Vorticella fusca, $5 \%$ were Dexitrichides pangi and $2 \%$ were Opisthonecta henneguyi. Those three species may be resistant to EHEC as they remained at very low numbers in untreated sludge sample. Their phylogenetic relationship is demonstrated in Figure 1, along with EHEC resistant ciliates Vorticella microstoma, Platyophyra bromelicola and Colpoda aspera identified by Ravva et al. [13].

\subsection{T-RFLP}

The T-RFLP AMMI analysis of ciliate 18S rDNA genes (Figure 2) showed differences between the E. coli EDL 933 strain, the K-12 strain, and the no bacteria added control microcosms, based on MspI and RsaI restrictions of triplicate samples. The T-RFLP pattern of original sludge sample at day 0 was different from the patterns of no bacteria added controls at day 10 and day 25, while the patterns from day 10 and day 25 controls were quite close to each other. Without adding new bacteria as food source, the original ciliate population could starve and thus the population would change. At day 10 and day 25, EDL 933-treated ciliate populations were different from K-12-treated ciliate populations (Figure 2). At day 25, EDL 933-treated ciliate populations were more similar to no bacteria added controls, than the K-12-added ciliate populations.

The T-RFs average abundance from each T-RFLP file was also analyzed (Table 2). Base on the one-way ANOVA test, the numbers of T-RFs from the EDL 933-treated samples and K-12-treated samples, and the no bacteria added controls were not significant different at day 10 in $R s a$ I restricted samples $\left(F_{2,6}=1.431, p=0.31\right)$. At day 25, the number of T-RFs from the three types of treatments were not significant different from each other in MspI restricted samples $\left(F_{2,6}=0.54, p=0.609\right)$ and $R s a$ I restricted samples $\left(F_{2,6}=0.201, p=0.823\right)$. Al-

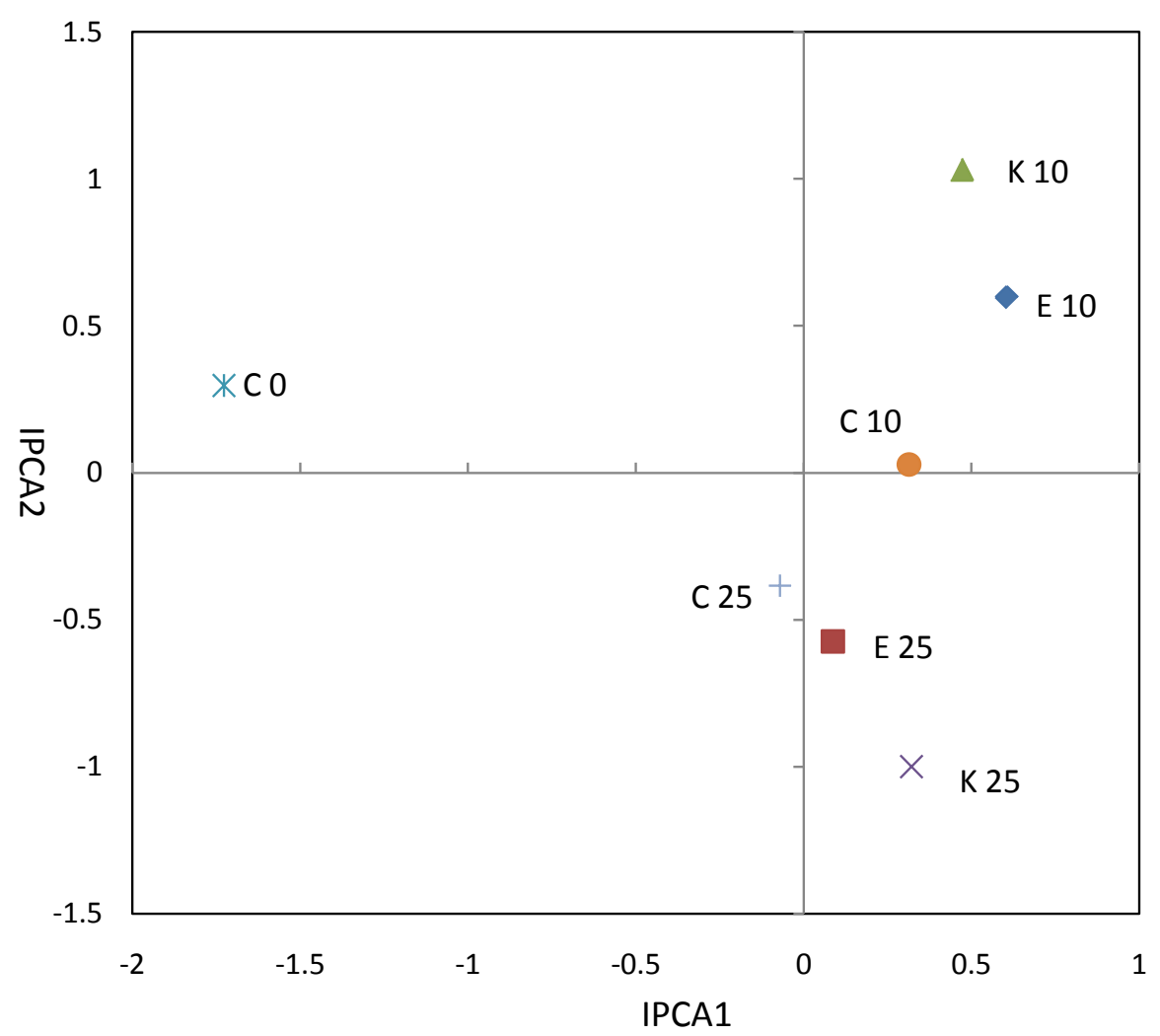

Figure 2. T-RFLP analysis with MspI and RsaI restriction from triplicate samples via AMMI model, which uses analysis of variance (ANOVA) to first partition the variation into main effects and interactions, and then applies PCA to the interactions to create interaction principal components axes (IPCAs). (E10 = EDL 933-treated samples at day 10, E25 = EDL 933-treated samples at day 25; K10 = K-12-treated samples at day 10, K25 = K-12-treated samples at day 25; C0 = control samples at day $0 ; \mathrm{C} 10=$ control samples at day $10, \mathrm{C} 25=$ control samples at day 25). 
Table 2. Average T-RFs from different samples $(n=3$, mean \pm standard deviation).

\begin{tabular}{ccccccc}
\hline & \multicolumn{2}{c}{ MspI restriction } & \multicolumn{2}{c}{ RsaI restriction } \\
\cline { 2 - 7 } & $\begin{array}{c}\text { EDL 933-treated } \\
\text { samples }\end{array}$ & $\begin{array}{c}\text { K-12-treated } \\
\text { samples }\end{array}$ & $\begin{array}{c}\text { Control } \\
\text { samples }\end{array}$ & $\begin{array}{c}\text { EDL 933-treated } \\
\text { samples }\end{array}$ & $\begin{array}{c}\text { K-12-treated } \\
\text { samples }\end{array}$ & Control samples \\
\hline Day 0 & - & - & $53^{\mathrm{b}}$ & - & - & $31^{\mathrm{b}}$ \\
Day 10 & $59 \pm 40$ & $50^{\mathrm{a}}$ & $33 \pm 18$ & $48 \pm 25$ & $47 \pm 31$ & $20 \pm 1$ \\
Day 25 & $46 \pm 35$ & $63 \pm 55$ & $31 \pm 5$ & $30 \pm 17$ & $30 \pm 19$ & $23 \pm 9$ \\
\hline
\end{tabular}

${ }^{\mathrm{a}}$ Number of T-RFs from K-12-treated samples in day 10 with $M$ spI restriction $(\mathrm{n}=2)$; ${ }^{\mathrm{b}}$ Number of T-RFs from original sample in day 0 ( $\left.\mathrm{n}=1\right)$.

though the AMMI analysis showed that EDL 933-treated ciliate populations were different from the K-12-treated ones, the numbers of T-RFs were not significantly different from each other.

\section{Discussion}

Based on our results, ciliates can consume E. coli EHEC and non-EHEC strains in aeration microcosms inoculated with activated sludge samples. The total bacterial density dropped from $10^{8}$ to $10^{4} \mathrm{ml}^{-1}$ in 4 days, which is similar to dairy lagoon wastewater experiments where EHEC density dropped from $2 \times 10^{7}$ to $10^{4} \mathrm{ml}^{-1}$ [13]. However, the addition of the $10 \mathrm{ml} 0.1 \%$ peptone solution that contained $E$. coli could possibly bring nutrients to the microcosm and stimulate ciliates to ingest more E. coli cells. Similar observations were reported that cereal grass medium enhanced Platyophyra sp. to remove EHEC [13].

Our study also indicated that EHEC and non-EHEC E. coli food sources could have different impacts on the sewage ciliate populations as seen from the T-RFLP analysis. The T-RFLP patterns from the AMMI model indicated that protozoan populations in no bacteria added control samples, EDL 933-treated samples and the K-12-treated samples changed at day 10 and 25. This could indicate that external food sources could change ciliate populations in sewage systems.

In this study, the diversity of ciliate populations might have been underestimated in activated sludge. Several BLAST searches of Day 0 control clones with the same result (Epistylis wenrichi) had different similarity scores (93\%, 95\%, 96\% and 97\%) (Table 1). This could be caused by lack of adequate identified ciliate 18S rDNA sequences in NCBI database or could represent a high level of strain variation in this species that was present in the ciliate population, which perhaps reflects niche specialization in this organism in the activated sludge. This could also be supported by the fact that 31 T-RFs in RsaI restriction analysis and 53 T-RFs in MspI restriction analysis were found in the day 0 control sample T-RFLP analysis (Table 2), while only two species were identified in the same sample (Epistylis wenrichi and Prorodon teres).

Studies have suggested that some ciliate species could reduce EHEC concentrations in dairy lagoon wastewater. These species include Vorticella microstoma, Platyophyra bromelicola and Colpoda aspera [13]. Similarly, a Vorticella species (Vorticella fusca) was also found in EHEC treated domestic sewage water in our study. However, this study could not determine which of these EHEC tolerant ciliate species could decrease EHEC from domestic wastewater. In order to do that, further studies would be needed to study individual ciliate species discovered in this study.

This study may also indicate that some ciliate species are more resistant to EHEC than others in the aeration tank of municipal sewage treatment plants. It is known that EHEC strain EDL 933 could kill ciliate Tetrahymena pyriformis by using Stx toxins [7] [8]. In our study, Epistylis wenrichi clones were only found in original activated sludge samples, but not in EDL 933-treated ones after 53 days. Nevertheless, Vorticella fusca and Opisthonecta henneguyi clones were found in the EDL 933-treated sludge sample, and were not detected in the untreated ones. These three ciliate species belong to the subclass Peritrichia, which is the most important ciliate subclass in the aerobic processes [20]. Thus, Epistylis wenrichi might be less tolerant to EHEC than Vorticella fusca and Opisthonecta henneguyi. Dexitrichides pangi belongs to the subclass Scuticociliatia and its clones are only found in the EDL 933-treated sludge sample, indicating that it may be more resistant to EHEC. Prorodon teres clones were found in both untreated and EDL 933-treated sludge samples, indicating that it might serve as a stable bacterivore ciliate in activated sludge with being less affected by EHEC. The presence of the EDL 933 pathogens might reduce the proportion of ciliates that were able to out-compete EDL 933-resistant ciliates under "normal" conditions, thereby enabling them to become dominant members of the population when EDL 933 was 
present. However, further research would be needed to confirm the sensitivity of those identified ciliates to EHEC.

In this study, the impact of EHEC and non-EHEC on ciliate populations were observed in activated sludge from municipal sewage systems. The ciliate population in activated sludge could be affected by EHEC, and also non-EHEC populations. Several potentially EHEC sensitive and resistant ciliate species were also identified. In order to further understand the relationships between bacteria and their ciliate predators in municipal sewage systems, future work could be done to exam the sewage microbial communities under the influence of EHEC and EHEC resistant ciliate protozoan populations.

\section{Acknowledgements}

This research was supported by Grant No. G110816 from the Graduate Student Research and Scholarship Committee and the Molecular Research Core Facility Seed Grant at Idaho State University in Pocatello, Idaho. We would like to thank Erin O’Leary-Jepsen and Christine Ryan at Idaho State University Molecular Research Core Facility for the DNA sequencing.

\section{References}

[1] Slayton, R.B., Turabelidze, G., Bennett, S.D., Schwensohn, C.A., Yaffee, A.Q., et al. (2013) Outbreak of Shiga Toxin-Producing Escherichia coli (STEC) O157:H7 Associated with Romaine Lettuce Consumption, 2011. PLoS ONE, 8, e55300. http://dx.doi.org/10.1371/journal.pone.0055300

[2] Joensen, K.G., Scheutz, F., Lund, O., Hasman, H., Kaas, R.S., Nielsen, E.M. and Aarestrup, F.M. (2014) Real-Time Whole-Genome Sequencing for Routine Typing, Surveillance, and Outbreak Detection of Verotoxigenic Escherichia coli. Journal of Clinical Microbiology, 52, 1501-1510. http://dx.doi.org/10.1128/JCM.03617-13

[3] Pennington, T.H. (2014) E. coli O157 Outbreaks in the United Kingdom: Past, Present, and Future. Infection and Drug Resistance, 7, 211-222. http://dx.doi.org/10.2147/IDR.S49081

[4] Riley, L.W., Remis, R.S., Helgerson. S.D., McGee, H.B., Wells, J.G. and Davis, B.R. (1983) Hemorrhagic Colitis Associated with a Rare Escherichia coli Serotype. New England Journal of Medicine, 308, 681-685. http://dx.doi.org/10.1056/NEJM198303243081203

[5] O’Brien, A.O., Lively, T.A., Chen, M.E., Rothman, R.W. and Formal, S.B. (1983) Escherichia coli O157:H7 Strains Associated with Haemorrhagic Colitis in the United States Produce a Shigella dysenteriae 1 (Shiga) Like Cytotoxin. Lancet, 321, 702. http://dx.doi.org/10.1016/S0140-6736(83)91987-6

[6] Newland, J.W., Strockbine, N.A., Miller, S.F., O’Brien, A.D. and Holmes, R.K. (1985) Cloning of Shiga-Like Toxin Structural Genes from a Toxin Converting Phage of Escherichia coli. Science, 230, 179-181. http://dx.doi.org/10.1126/science.2994228

[7] Steinberg, K.M. and Levin, B.R. (2007) Grazing Protozoa and the Evolution of the Escherichia coli O157:H7 Shigatoxin-Encoding Prophage. Proceedings of the Royal Society B, 274, 1921-1929. http://dx.doi.org/10.1098/rspb.2007.0245

[8] Lainhart, W., Stolfa, G. and Koudelka, G.B. (2009) Shiga Toxin as a Bacterial Defense against a Eukaryotic Predator, Tetrahymena thermophila. Journal of Bacteriology, 191, 5116-5122. http://dx.doi.org/10.1128/JB.00508-09

[9] Lee, S.H., Levy, D.A., Craun, G.F., Beach, M.J. and Calderon, R.L. (2002) Surveillance for Waterborne-Disease Outbreaks-United States, 1999-2000. MMWR Surveillance Summaries, 51, 1-47.

[10] Ravva, S.V., Sarreal, C.Z., Duffy, B. and Stanker, L.H. (2006) Survival of Escherichia coli O157:H7 in Wastewater from Dairy Lagoons. Journal of Applied Microbiology, 101, 891-902. http://dx.doi.org/10.1111/j.1365-2672.2006.02956.x

[11] Solomon, E.B., Yaron, S. and Matthews, K.R. (2002) Transmission of Escherichia coli O157:H7 from Contaminated Manure and Irrigation Water to Lettuce Plant Tissue and Its Subsequent Internalization. Applied and Environmental Microbiology, 68, 397-400. http://dx.doi.org/10.1128/AEM.68.1.397-400.2002

[12] Bach, S.J., McAllister, T.A., Veira, D.M., Gannon, V.P.J. and Holley, R.A. (2002) Transmission and Control of Escherichia coli 157:H7-A Review. Canadian Journal of Animal Science, 82, 475-490. http://dx.doi.org/10.4141/A02-021

[13] Ravva, S.V., Sarreal, C.Z. and Mandrell, R.E. (2010) Identification of Protozoa in Dairy Lagoon Wastewater That Consume Escherichia coli O157:H7 Preferentially. PLOS ONE, 5, e15671. http://dx.doi.org/10.1371/journal.pone.0015671

[14] Gantalupo, P.G., Calgua, B., Zhao, G., Hundesa, A., Wier, A.D., Katz, J.P., Grabe, M., Hendrix, R.W., Girones, R., Wang, D. and Pipas, J.M. (2011) Raw Sewage Harbors Diverse Viral Populations. mBio, 2, Article ID: e00180-11. http://dx.doi.org/10.1128/mbio.00180-11 
[15] Elmund, G.K., Allen, M.J. and Rice, E.W. (1999) Comparison of Escherichia coli, Total Coliform, and Fecal Coliform Populations as Indicators of Wastewater Treatment Efficiency. Water Environment Research, 71, 332-339. http://dx.doi.org/10.2175/106143098X121752

[16] Grant, S.B., Pendroy, C.P., Mayer, C.L., Bellin, J.K. and Palmer, C.J. (1996) Prevalence of Enterohemorrhagic Escherichia coli in Raw and Treated Municipal Sewage. Applied and Environmental Microbiology, 62, 3466-3469.

[17] Martinez-Castillo, A., Allue-Guardia, A., Dahbi, G., Blanco, J., Creuzburg, K., Schmidt, H. and Muniesa, M. (2011) Type III Effector Genes and Other Virulence Factors of Shiga toxin-Encoding Escherichia coli Isolated from Wastewater. Environmental Microbiology Reports, 4, 147-155. http://dx.doi.org/10.1111/j.1758-2229.2011.00317.x

[18] Muniesa, M., Serra-Moreno, R. and Jofre, J. (2004) Free Shiga toxin Bacteriophages Isolated from Sewage Showed Diversity although the stx Genes Appeared Conserved. Environmental Microbiology, 6, 716-725. http://dx.doi.org/10.1111/j.1462-2920.2004.00604.x

[19] Hahn, M.W. and Höfle, M.G. (2001) Grazing of Protozoa and Its Effect on Populations of Aquatic Bacteria. FEMS Microbiology Ecology, 35, 113-121. http://dx.doi.org/10.1111/j.1574-6941.2001.tb00794.x

[20] Curds, C.R. (1982) The Ecology and Role of Protozoa in Aerobic Sewage Treatment Processes. Annual Review of Microbiology, 36, 27-46. http://dx.doi.org/10.1146/annurev.mi.36.100182.000331

[21] Snaidr, J., Amann, R., Huber, I., Ludwig, W. and Schleifer, K. (1997) Phylogenetic Analysis and in Situ Identification of Bacteria in Activated Sludge. Applied and Environmental Microbiology, 63, 2884-2896.

[22] Zhou, K., Xu, M., Liu, B. and Cao, H. (2008) Characteristics of Microfauna and Their Relationships with the Performance of an Activated Sludge Plant in China. Journal of Environmental Sciences, 20, 482-486. http://dx.doi.org/10.1016/S1001-0742(08)62083-5

[23] Madoni, P. (1994) A Sludge Biotic Index (SBI) for the Evaluation of the Biological Performance of Activated Sludge Plants Based on the Microfauna Analysis. Water Research, 28, 67-75. http://dx.doi.org/10.1016/0043-1354(94)90120-1

[24] Fitzpatrick, A.H. (2010) Detection, Quantification, and Sequencing of stx1 and stx2 in Southeastern Idaho Wastewater Treatment Facilities. Master's Thesis, Idaho State University, Pocatello.

[25] King, W.L. and Hurst, A. (1963) A Note on the Survival of Some Bacteria in Different Diluents. Journal of Applied Bacteriology, 26, 504-506. http://dx.doi.org/10.1111/j.1365-2672.1963.tb04803.x

[26] Reynolds, J. (2005) Serial Dilution Protocols. ASM Microbe Library. http://www.microbelibrary.org/component/resource/laboratory-test/2884-serial-dilution-protocols

[27] Li, Z., Haynes, R., Sato, E., Shields, M.S., Fujita, Y. and Sato, C. (2014) Microbial Community Analysis of a Single Chamber Microbial Fuel Cell Using Potato Wastewater. Water Environment Research, 86, 324-330. http://dx.doi.org/10.2175/106143013X13751480308641

[28] Dopheide, A., Lear, G., Stott, R. and Lewis, G. (2008) Molecular Characterization of Ciliate Diversity in Stream Biofilms. Applied and Environmental Microbiology, 74, 1740-1747. http://dx.doi.org/10.1128/AEM.01438-07

[29] Birnboim, C. and Doly, J. (1979) A Rapid Alkaline Extraction Procedure for Screening Recombinant Plasmid DNA. Nucleic Acids Research, 7, 1513-1523. http://dx.doi.org/10.1093/nar/7.6.1513

[30] Li, Z., Briggs, B.R., Sheridan, P.P. and Shields, M.S. (2013) An Anion-Exchange Method to Concentrate Dissolved DNA from Aquifer Water. Journal of Microbiological Methods, 93, 1-8. http://dx.doi.org/10.1016/j.mimet.2013.01.014

[31] Martin, D.P., Lemey, P., Lott, M., Moulton, V., Posada, D. and Lefeuvre, P. (2010) RDP3: A Flexible and Fast Computer Program for Analyzing Recombination. Bioinformatics, 26, 2462-2463. http://dx.doi.org/10.1093/bioinformatics/btq467

[32] Tamura, K., Peterson, D., Peterson, N., Stecher, G., Nei, M. and Kumar, S. (2011) MEGA5: Molecular Evolutionary Genetics Analysis Using Maximum Likelihood, Evolutionary Distance, and Maximum Parsimony Methods. Molecular Biology and Evolution, 28, 2731-2739. http://dx.doi.org/10.1093/molbev/msr121

[33] Liu, W.T., Marsh, T.L., Cheng, H. and Forney, L.J. (1997) Characterization of Microbial Diversity by Determining Terminal Restriction Fragment Length Polymorphisms of Genes Encoding 16S rRNA. Applied and Environmental Microbiology, 63, 4516-4522.

[34] Culman, S.W., Bukowski, R., Gauch, H.G., Cadillo-Quiroz, H. and Buckley, D.H. (2009) T-REX: Software for the Processing and Analysis of T-RFLP Data. BMC Bioinformatics, 10, 171. http://dx.doi.org/10.1186/1471-2105-10-171

[35] Culman, S.W., Gauch, H.G., Blackwood, C.B. and Thies, J.E. (2008) Analysis of T-RFLP Data Using Analysis of Variance and Ordination Methods: A Comparative Study. Journal of Microbiological Methods, 75, 55-63. http://dx.doi.org/10.1016/j.mimet.2008.04.011

[36] Soper, D.S. (2015) Analysis of Variance (ANOVA) Calculator-One-Way ANOVA from Summary Data. http://www.danielsoper.com/statcalc 